\title{
Climate changes and cultural shifts on Easter Island during the last three millennia
}

\author{
Valentí Rull1', N. Cañellas-Boltà2 ${ }^{2}$ O. Margalef ${ }^{3}$ S. Pla-Rabes ${ }^{3}$, A. Sáez ${ }^{4}$ and S. Giralt ${ }^{1}$
}

\begin{abstract}
Easter Island's cultural shifts have been explained mostly by anthropogenic forcing and climate changes have been dismissed as relevant drivers of societal change. Recent findings demand a more complex scenario in which climatic, ecological and cultural factors interact.
\end{abstract}

Easter Island (Rapa Nui) is a small (164 $\mathrm{km}^{2}$ ) and remote Pacific island formed by the coalescence of three volcanic cones. The interior uplands are dominated by the Terevaka volcano (511 m elevation) to the north, and the rest of the island is characterized mostly by lowlands. Easter Island has been the home of several scientific enigmas including the chronology of its settlement by people, the origin of the first settlers, and the timing and causes of the disappearance of the ancient Rapanui civilization that built the megalithic statues known as moai.

The currently available evidence favors colonization from Eastern Polynesia (Fig. 1) between AD 800 and 1200 (Flenley and Bahn 2003; Hunt 2007; Wilmshurst et al. 2011). However, the breakdown of the ancient Rapanui culture is still debated. The more widely known theory is the occurrence of a cultural collapse following the anthropogenic deforestation of the island and the associated ecological catastrophe or ecocide (Diamond 2005). An opposing view is that deforestation was largely caused by massive tree-seed consumption by introduced Polynesian rats (Hunt 2007). According to this view, cultural collapse was not a consequence of deforestation but of slave trading and the introduction of unknown diseases after the European contact (AD 1722). Hypotheses on the potential influence of climatic changes have been traditionally underrated in favor of anthropogenic explanations (Flenley and Bahn 2003). In the last decade, however, important evidence for climatic shifts on the island and its regional context has grown, and proposals based solely on human pressure have been challenged.

\section{Early proposals}

The first proposals of a potential influence of climate on ecological and cultural shifts on Easter Island were based on theoretical assumptions, rather than on factual evidence. For example, McCall (1993), by analogy with other geographical areas, argued that droughts during the Little Ice Age (LIA; ca. 14th to 19th centuries) might have affected the island's ecosystems and human practices leading to relevant cultural changes. However, evidence of such changes on the island was still lacking Nunn (2007) proposed that Polynesian climates were relatively stable during the Medieval Climate Anomaly (MCA) but a phase of general instability and lower sea
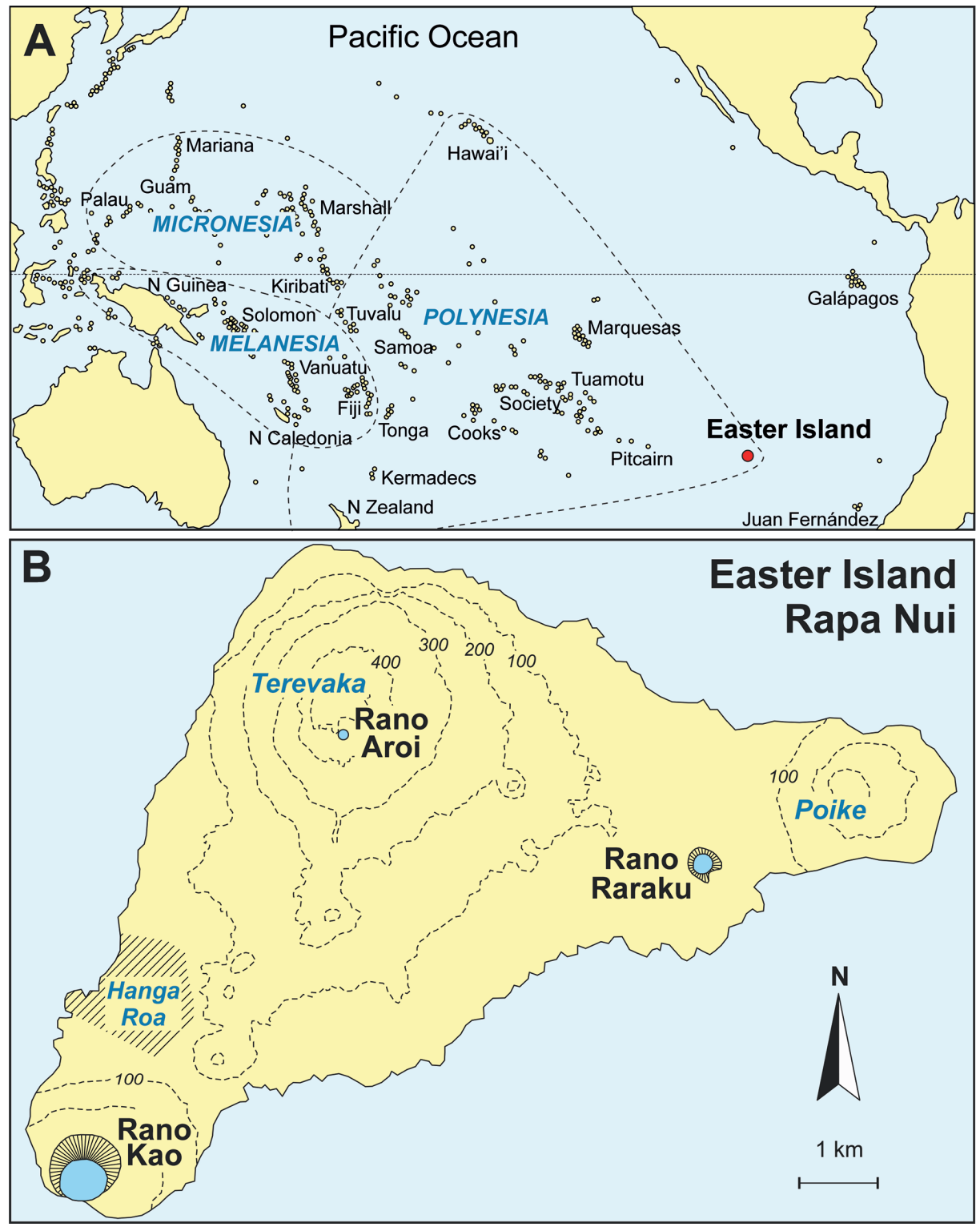

Figure 1: Location map. (A) The Pacific Ocean and its main archipelagos (Easter Island is highlighted by a red dot). (B) Sketch-map of Easter Island indicating the sites referred to in the text.

level started at AD 1300 and continued during the LIA, possibly caused by an intensification of the El Niño-Southern Oscillation (ENSO) variability. This climatic reversal would have led to widespread ecological and social crises in the region, and the cessation of transoceanic navigation. According to Nunn (2007), the cultural shift that represented the end of the ancient moai-building Rapanui society was a consequence of the LIA climatic deterioration but direct in situ evidence of climatic changes on the island remained to be demonstrated.

Azizi and Flenley (2008) studied sediments from Lake Raraku (Fig. 1) corresponding to the Last Glacial Maximum (LGM) and found palynological evidence of forest continuity, in spite of the presumed temperature and moisture declines. These authors concluded that if forests were resilient to climatic changes as intense as the LGM, 
further late glacial and Holocene environmental shifts of lower intensity could not have been responsible for the island's deforestation. This reinforced the view that the recent historical deforestation should have been anthropogenic, rather than of climatic origin. The influence of the ENSO variability was dismissed on the basis of instrumental records of the second half of the 20th century and modeling results showing that such interannual periodical forcing was unable to cause significant variations in precipitation patterns during the last millennium (Genz and Hunt 2003; Junk and Claussen 2011).

\section{Climate changes}

During the last two decades, paleoecological and paleoclimatic research on Easter Island has intensified and new sedimentary records have been obtained that provide new evidence for climatic changes during the last millennia. The first records suggesting the occurrence of arid climates during the Late Holocene came from Lake Raraku, in the coastal lowlands, and were used to tentatively relate aridity and ecological shifts, especially associated to forest dynamics (Mann et al. 2008; Sáez et al. 2009). Further work on the same lake yielded an almost continuous record for the last 2700 years that provided evidence for two drought phases, between $\sim A D 880$ and 1170 and $\sim A D 1570$ and 1720 (CañellasBoltà et al. 2013). The peats of the Rano Aroi swamp, in the interior uplands (Fig. 1), provided a continuous record of a similar time period showing three phases of landscape opening (i.e. forest retraction) associated to drier climates at $300 \mathrm{BC}$ to AD 50, AD 600 to 1100 , and AD 1520 to 1700 (Rull et al. 2015). The two later phases roughly coincided with the Lake Raraku droughts and occurred during the MCA and the LIA, respectively (Fig. 2).

\section{Deforestation}

The Raraku and Aroi records showed heterogeneous deforestation patterns across the island. In Raraku, deforestation began by $450 \mathrm{BC}$ and was associated with the onset of charcoal and the pollen of Verbena litoralis, a weed of American origin (CañellasBoltà et al. 2013). This challenged previous theories of a unique colonization event from Polynesia by AD 800-1200. However, this is not a direct evidence of human presence and should be confirmed with further studies. In addition, archaeological evidence for such an early colonization (BC 450 ) is still lacking. The deforestation of this catchment was completed by AD 1530 (Fig. 2 ); therefore, forest clearing was a slow and gradual process elapsing two millennia. The situation was very different in the Aroi catchment, where forests remained virtually untouched until AD 1520 and were rapidly removed in roughly one century. This deforestation coincided with the appearance and sudden increase of charcoal particles suggesting anthropogenic burning (Rull et al. 2015). Another difference between the Raraku and Aroi sites was that, prior to deforestation, the first was occupied by dense forests whereas the second was covered by open forests (Fig. 2). This has been

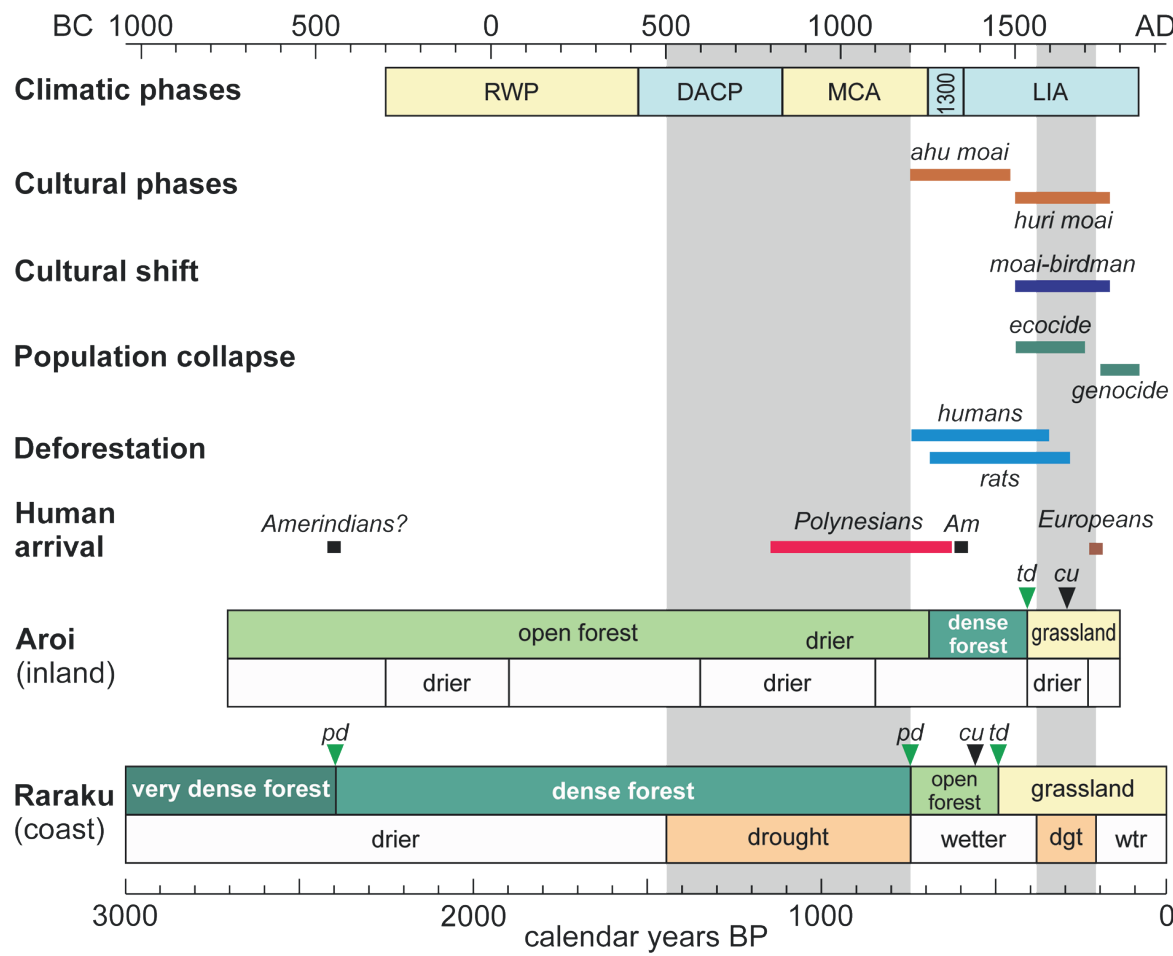

Figure 2: Summary of the climatic, ecological and cultural trends of Easter Island over the last three millennia (simplified from Rull et al. 2016). Drought phases are shaded. Horizontal bars represent the age range for the occurrence of the indicated cultural and environmental events, according to the available literature. Abbreviations: RWP $=$ Roman Warm Period, $\mathrm{DACP}=$ Dark Ages Cold Period, MCA $=$ Medieval Climate Anomaly, 1300 = "1300 event", LIA = Little Ice Age, Am = Americans, cu = first evidence of local cultivation, dgt = drought, $\mathrm{pd}=$ partial deforestation, $\mathrm{td}=$ total deforestation, $w \mathrm{wtr}=$ wetter.

explained in terms of altitudinal differences in the vegetation cover due to climatic constraints (Flenley and Bahn 2003), a hypothesis that has not been confirmed yet. In the Kao basin, the lack of a reliable chronology (Butler and Flenley 2010; Horrocks et al. 2013) complicates the interpretation, but the record showed the occurrence of two deforestation events, between AD 50 and 100, and AD 1350 and 1800 (Butler and Flenley 2010). Spatio-temporal differences in deforestation patterns agree with the apparent heterogeneity in land-use practices documented by archaeological evidence (Stevenson et al. 2015). The combined evidence obtained so far suggests a conspicuous pattern of coastal abandonment toward inland settlements, a common feature in many eastern Pacific archipelagos during the same times (Nunn 2007).

\section{A new scenario}

The concurrence of conspicuous climatic, ecological and cultural changes during the last millennia suggests that the recent history of Easter Island may be more complex than previously thought and that natural and anthropogenic drivers of change, as well as their potential synergies, might have been influential in determining cultural shifts (Rull et al. 2016). Rather than simplistic scenarios of single, simultaneous and island-wide cause-effect relationships, a holistic perspective that considers all the potential forcing factors should be pursued to explain Easter Island's landscape and cultural changes. Further research should be addressed under a new perspective including paleoecological, archaeological, anthropological and historical evidence. The incorporation of direct sedimentary evidence of human presence, such as fecal lipids or DNA, is strongly recommended (Rull et al. 2016).

\section{AFFILIATIONS}

IInstitute of Earth Sciences Jaume Almera (ICTJA-CSIC), Barcelona, Spain

Department of Prehistory, Ancient History and Archaeology, Universitat de Barcelona, Spain

${ }^{3}$ Ecological Research Center and Forestry Applications (CREAF), Cerdanyola del Vallès, Spain

${ }^{4}$ Department of Earth and Ocean Dynamics, Universitat de Barcelona, Spain

\section{CONTACT}

Valentí Rull: vrull@ictja.csic.es

REFERENCES

Azizi G, Flenley JR (2008) Quat Int 184: 166-176

Butler KR, Flenley JR (2010) Rapa Nui J 24: 5-10

Diamond JM (2005) Collapse: How Societies Choose to Fail or Succeed. Penguin, 608 pp

Cañellas-Boltà N et al. (2013) Quat Sci Rev 72: 36-48

Flenley JR, Bahn PG (2003) The Enigmas of Easter Island. Oxford University Press, $256 \mathrm{pp}$

Horrocks M et al. (2013) J Paleolimnol 50: 417-432

Genz J, Hunt TL (2003) Rapa Nui J 17: 7-17

Hunt TL (2007) J Archaeol Sci 34: 485-502

Junk C, Claussen M (2011) Clim Past 7: 579-586

Mann D et al. (2008) Quat Res 69: 16-28

McCall G (1993) Rapa Nui J 7: 65-70

Nunn PD (2007) Climate, Environment and Society in the Pacific During the Last Millennium. Elsevier, 316 pp

Rull V et al. (2015) Quat Sci Rev 126: 219-226

Rull V et al. (2016) Front Ecol Evol 4: 29, doi 10.3389/ fevo.2016.00029

Sáez A et al. (2009) Quat Sci Rev 28: 2743-2759

Stevenson CM et al. (2015) PNAS 112: 1025-1030 Wilmshurst JM et al. (2011) PNAS 105: 7676-7680 